Review

\title{
Synthetic Approaches and Biological Activities of 4-Hydroxycoumarin Derivatives
}

\author{
Jae-Chul Jung ${ }^{1}$ and Oee-Sook Park ${ }^{2, *}$
}

1 Ewha Global Challenge, BK21 and Medical Research Institute, School of Medicine, Ewha Womans University, Seoul 158-710, Korea; E-Mail: jcjung10@yahoo.co.kr (J.-C.J.)

2 Department of Chemistry, Institute for Basic Sciences, College of Natural Sciences, Chungbuk National University, Cheongju 361-763, Chungbuk, Korea

* Author to whom correspondence should be addressed; E-Mail: ospark@cbnu.ac.kr.

Received: 19 October 2009; in revised form: 16 November 2009 / Accepted: 18 November 2009 / Published: 23 November 2009

\begin{abstract}
The main purpose of this review is to summarize recent chemical syntheses and structural modifications of 4-hydroxycoumarin and its derivatives, of interest due to their characteristic conjugated molecular architecture and biological activities.
\end{abstract}

Keywords: 4-hydroxycoumarin; anticoagulant; rodenticide; ring cyclization; tetralone; coupling reaction

\section{Introduction}

4-Hydroxycoumarins (2H-1-benzopyran-2-ones, Figure 1) have evoked a great deal of interest due to their biological properties and characteristic conjugated molecular architecture. Many of them display important pharmacological effects, including analgesic [1], anti-arthritis [2], anti-inflammatory [3], anti-pyretic [4], anti-bacterial [5], anti-viral [6], and anti-cancer [7] properties. 4-Hydroxycoumarin and its derivatives have been effectively used as anticoagulants for the treatment of disorders in which there is excessive or undesirable clotting, such as thrombophlebitis [8], pulmonary embolism [9], and certain cardiac conditions [10]. A number of comparative pharmacological investigations of the 4-hydroxycoumarin derivatives have shown good anticoagulant activity combined with low side effects and little toxicity [11]. 
Figure 1. Structures of the 4-hydroxycoumarin (1), 4-hydroxythiocoumarin (2), and derivatives 3-6.<smiles>[X]c1ccccc2c(O)cc(=O)cc1-2</smiles>

$1 \mathrm{X}=\mathrm{O}, 4$-Hydroxycoumarin $2 \mathrm{X}=\mathrm{S}$, 4-Hydroxythiocoumarin<smiles>CC(=O)CC(c1ccccc1)c1c(O)c2ccccc2oc1=O</smiles>

3 Warfarin<smiles>O=c1oc2ccccc2c(O)c1C1CCCc2ccccc21</smiles>

4 Coumatetralyl<smiles>O=c1oc2ccccc2c(O)c1C1CC(c2ccc(OCc3ccc(C(F)(F)F)cc3)cc2)Cc2ccccc21</smiles>

5 Flocoumafen<smiles>O=c1sc2ccccc2c(O)c1C1CC(c2ccc(OCc3ccc(C(F)(F)F)cc3)cc2)Cc2ccccc21</smiles>

6 Difethialone

Nowadays 4-hydroxycoumarin and its derivatives are widely used anticoagulant rodenticides as well as antithrombotic agents [12]. The 4-hydroxycoumarin anticoagulants are antagonists of vitamin $\mathrm{K}$ and their target is vitamin $\mathrm{K}$ 2,3-epoxide reductase in the liver microsomes. Finally, they are also useful key intermediates for many industrial products such as dyes [13] and liquid crystals [14].

The chemical synthesis, structural modification, and a wide variety of biological activities of 4hydroxycoumarins have been reported in many papers [15-17]. The goal of this review is to summarize recent synthetic approaches to 4-hydroxycoumarin derivatives and their biological activities.

\section{Results and Discussion}

The 2H-1-benzopyran-2-one and tetrahydronaphthalen-1-ols skeletons are essential structural features in the second generation rodenticide 4-hydroxycoumarin derivatives. They have traditionally been coupled in acidic media. Although several improved condensation reactions of 4-hydroxycoumarin (1) with compounds 8-9 using Bronsted-Lowry acids $\left(\mathrm{HCl}, \mathrm{H}_{2} \mathrm{SO}_{4}, p\right.$-TsOH) have been reported [18-21], these reactions led to preferential dehydrohalogenation, resulting in low yields. Thus, an efficient coupling condition was required to obtain better yield. Scheme 1 shows a representative retrosynthetic approach for this class of molecules. The tetrahydronaphthalen-1-ol 8 was coupled with 4-hydroxycoumarin (1) or 4-hydroxythiocoumarin (2) to generate the target $2 \mathrm{H}$-1-benzopyran-2-one or 2H-1-benzothiopyran-2-one. 
Scheme 1. Retrosynthetic analysis of the 4-hydroxycoumarin derivatives.



7<smiles>O=c1cc(O)c2ccccc2o1</smiles>

1



$8 \mathrm{Y}=\mathrm{OH}, \mathrm{R}=$ phenyl or benzyl groups

$9 \mathrm{Y}=\mathrm{Br}, \mathrm{R}=\mathrm{phenyl}$ or benzyl groups

Our previous synthesis of flocoumafen (5) [18-19] is summarized in Scheme 2. Its main reactions were Friedel-Crafts acylation, Reformatsky reaction, and dehydration. Commercially available phenylacetyl chloride (10) was condensed with anisole (11) in the presence of $\mathrm{AlCl}_{3}$ to afford ketone 12, which was treated with ethyl bromoacetate to give hydroxyl ethyl ester 13 in $86 \%$ yield over two steps. Subsequent dehydroxylation of ethyl ester 13 was accomplished with triethylsilane and boron trifluoride to give the corresponding ester, which was smoothly hydrolyzed under basic conditions and cyclized using polyphosphoric acid to yield tetralone 14 in three steps. Reduction of tetralone 14 with sodium borohydride afforded secondary alcohol 15, which was then coupled with 4-hydroxycoumarin in the presence of $p$-toluenesulfonic acid to give compound 16. Demethylation of compound 16 was performed with hyrobromic acid in acetic acid to give phenol 17. Phenol 17 was $O$-alkylated with freshly prepared 3-(trifluoromethyl)benzyl bromide in sodium hydride/THF to generate flocoumafen (5) in good yield (overall yield was $25 \%$ in eight steps).

The Ferreira group [20] has developed to a new protocol for the synthesis of diphenacoum (29) and brodifacoum (30). The key step involves the stereospecific formation of one of the crucial bonds in the molecular backbone using asymmetric organocopper 1,4-addition to chiral imides. Wittig condensation of freshly prepared aldehydes 18, 19, and (carbethoxy)triphenylphosphonium chloride (20) in the presence of sodium methoxide in DMF gave the biphenyl esters 21, 22 in $92 \%$ and $87 \%$ yield, respectively. Organocopper methodology was then successfully applied to the synthesis of butanoate. 1,4-Michael addition with compounds 21, 22 and BnCu-TMEDA complex in the presence of TMS-Cl generated 23, 24 in $84 \%$ and $81 \%$ yield, respectively, and then subsequent ring cyclization by using $\mathrm{AlCl}_{3}$ in toluene to give tetralones 25 and 26 in $88 \%$ and $86 \%$ yield, respectively. The coupling reaction between 4-hydroxycoumarin 1 and secondary alcohol 27 or brominated compound 28 under an $\mathrm{HCl}$ atmosphere at $160{ }^{\circ} \mathrm{C} 30 \mathrm{~min}$ provided approximately equal quantities of the cis and trans isomers of 4-hydroxycoumarin derivatives $\mathbf{2 9}$ and $\mathbf{3 0}$ in 78\% and 74\% yield, respectively (Scheme 3). 
Molecules 2009, 14

4793

Scheme 2. Synthesis of flocoumafen (5).<smiles>COc1ccccc1</smiles>

10 a

11



12
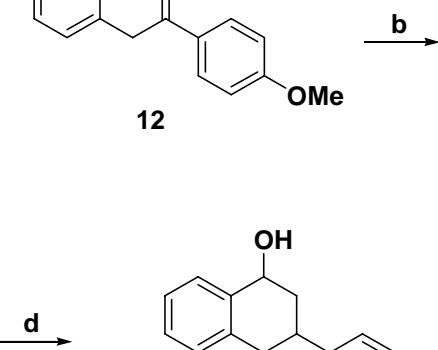

$\stackrel{\text { g }}{\longrightarrow}$

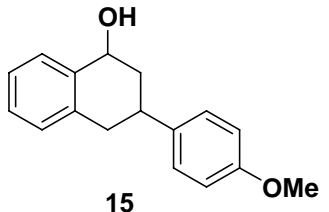

15



13

c
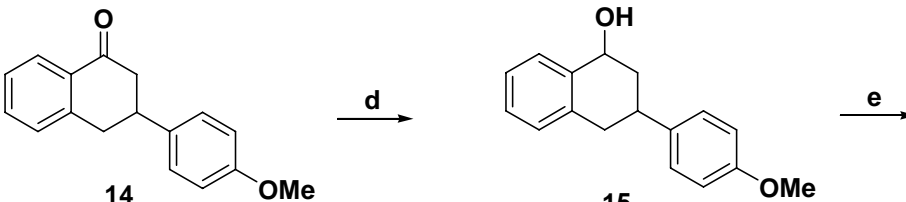

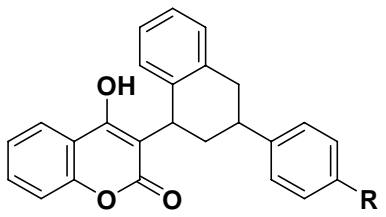

$\mathrm{f} \square 16 \mathrm{R}=\mathrm{OMe}$

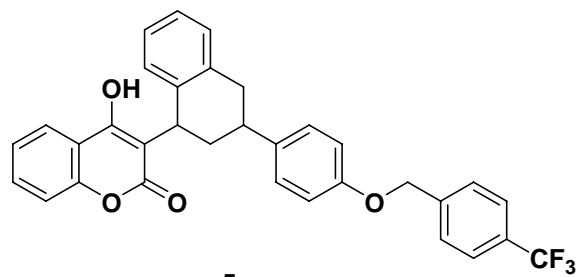

5

Reagents and conditions: (a) $\mathrm{AlCl}_{3}, \mathrm{CH}_{2} \mathrm{Cl}_{2},-10^{\circ} \mathrm{C}, 16 \mathrm{~h}$; (b) Zinc, $\mathrm{I}_{2}, \mathrm{BrCH}_{2} \mathrm{CO}_{2} \mathrm{Et}$, benzene, reflux, $1 \mathrm{~h}$; (c) (Et) $)_{3} \mathrm{SiH}, \mathrm{TFA}, \mathrm{BF}_{3} \mathrm{EtO}_{2}, \mathrm{CH}_{2} \mathrm{Cl}_{2}$, reflux, $8 \mathrm{~h}$; KOH/ $\mathrm{H}_{2} \mathrm{O}$, reflux, $8 \mathrm{~h}$; and then PPA, $80{ }^{\circ} \mathrm{C}, 1 \mathrm{~h}$; (d) $\mathrm{NaBH}_{4}, \mathrm{MeOH}, \mathrm{rt}, 2 \mathrm{~h}$; (e) 4-hydroxcoumarin, $p$-TsOH, $80{ }^{\circ} \mathrm{C}, 3 \mathrm{~h}$; (f) $\mathrm{HBr}, \mathrm{AcOH}$, reflux, $6 \mathrm{~h}$; (g) 3-(trifluoromethyl)benzyl bromide, sodium hydride, THF, $0^{\circ} \mathrm{C}, 1 \mathrm{~h}$

Scheme 3. Synthesis of diphenacoum (29) and brodifacoum (30).

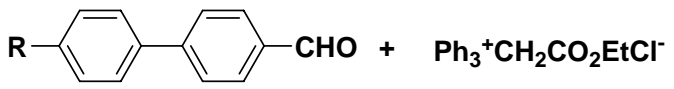

$18 \mathrm{R}=\mathrm{H}$ $19 \mathrm{R}=\mathrm{Br}$

<smiles>[R]c1ccc(-c2ccc(C(CC(=O)OCC)Cc3ccccc3)cc2)cc1</smiles>

$23 \mathrm{R}=\mathrm{H}$ $24 \mathrm{R}=\mathrm{Br}$<smiles>[R]c1ccc(-c2ccc(C3Cc4ccccc4C([X])C3)cc2)cc1</smiles>

$27 \mathrm{X}=\mathrm{OH}, \mathrm{R}=\mathrm{H}$ $28 \mathrm{X}=\mathrm{OH}, \mathrm{R}=\mathrm{Br}$
20

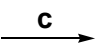<smiles>O=c1cc(O)c2ccccc2o1</smiles>

1
<smiles>[R]c1ccc(-c2ccc(C3CC(=O)c4ccccc4C3)cc2)cc1</smiles>

e

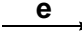<smiles>[R]c1ccc(-c2ccc(C3Cc4ccccc4C(c4c(O)c5ccccc5oc4=O)C3)cc2)cc1</smiles>

$$
\stackrel{\text { d }}{\longrightarrow}
$$

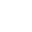

Reagents and conditions: (a) NaOMe, DMF; (b) BnCu-TMEDA, TMSCl, THF, $-78{ }^{\circ} \mathrm{C}$ to $30{ }^{\circ} \mathrm{C}$;

(c) $\mathrm{AlCl}_{3}$, toluene, $90{ }^{\circ} \mathrm{C}$; (d) $\mathrm{NaBH}_{4}, \mathrm{EtOH} / \mathrm{THF}$, rt, then $\mathrm{PBr}_{3}$, dichloromethane, $0{ }^{\circ} \mathrm{C}$; (e) $\mathrm{HCl}(\mathrm{g})$, $160{ }^{\circ} \mathrm{C}$. 
The Yang group [21] reported the synthesis of novel diphenacoum analogues using base-catalyzed aldol condensation, ring cyclization, and coupling reactions. 2-Hydroxyacetophenone (31) was treated with aldehydes $\mathbf{3 2}$ or $\mathbf{3 3}$ under base-catalyzed aldol reaction conditions to produce ketones $\mathbf{3 4}$, 35, which were readily cyclized by phosphoric acid in ethanol to give 2-biphenylchroman-4-ones 36 and 37, respectively. Reduction of $\mathbf{3 6}$ and $\mathbf{3 7}$ with sodium borohydride in methanol gave quantitative yields of the corresponding alcohols $\mathbf{3 8}$ and 39, which were then condensed with 4-hydroxycoumarin (1) in 1,2-dichloroethane in the presence of a catalytic amounts of $p$-toluenesulfonic acid, to yield the target compounds 40 and 41, respectively (Scheme 4).

Scheme 4. Synthesis of novel diphenacoum analogues.<smiles>CC(=O)c1ccccc1O</smiles>

31<smiles>[R]c1ccc(C=O)cc1</smiles>

$32 \mathrm{R}=\mathrm{H}$<smiles>[B]C</smiles><smiles>[R]c1ccc(/C=C/C(=O)c2ccccc2O)cc1</smiles><smiles>[R]c1ccc(C2CC(=O)c3ccccc3O2)cc1</smiles>

$36 \mathrm{R}=\mathrm{H}$ $37 \mathrm{R}=\mathrm{Ph}$<smiles>[R]c1ccc(C2CC(O)c3ccccc3O2)cc1</smiles>

$38 \mathrm{R}=\mathrm{H}$ $39 \mathrm{R}=\mathrm{Ph}$

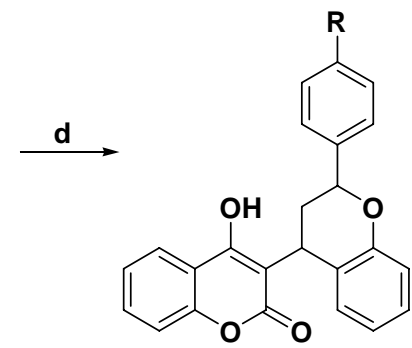

$40 \mathrm{R}=\mathrm{H}$

$41 \mathrm{R}=\mathrm{Ph}$

Reagents and conditions: (a) 40\% KOH; (b) $\mathrm{H}_{3} \mathrm{PO}_{4}, \mathrm{EtOH}$; (c) $\mathrm{NaBH}_{4}, \mathrm{MeOH} / \mathrm{THF}$; (d) 4 hydroxycoumarin, $p$-TsOH, 1,2-DCE.

The Danchev group [22] reported a synthesis of 4-hydroxcoumarin derivatives and their anticoagulant activities. Their method involves a condensation reaction of 4-hydroxcoumarin (1) with unsaturated ketone 42 or substituted aromatic aldehydes 32-33 (Scheme 5). Warfarin type compound 43 showed similar anticoagulant effect as coumachlor or warfarin in vivo, while its acute toxicity was higher than that of woumachlor. Among their 4-hydroxcoumarin derivatives 3,3'-(4chlorophenylmethylene)-bis-(4-hydroxy-2H-1-benzopyran-2-one), with low toxicity, is a prospective lead compound.

Scheme 5. Danchev synthesis of 4-hydroxcoumarin derivatives.<smiles>O=c1cc(O)c2ccccc2o1</smiles>

1<smiles>[R]c1ccc(/C=C/C(C)=O)cc1</smiles>

42

<smiles>[R]c1ccc(C(CC(C)=O)c2c(O)c3ccccc3oc2=O)cc1</smiles>

43

Reagents and conditions: (a) pyridine, sodium hydroxide, EtOH. 
The Hamdi group [23] prepared benzopyranodicoumarins 46 and 49 and evaluated their antioxidative and antibacterial activities. Aromatic aldehydes $\mathbf{4 4}$ containing different groups in the ortho-, meta- or para- positions was condensed with 4-hydroxycoumarin (1) in ethanol and acetic acid to generate substituted 3,3'-arylidenebis-4-hydroxycoumarins 45 and tetrakis-4-hydroxycoumarin derivatives 48. Heating of compounds $\mathbf{4 5}$ and $\mathbf{4 8}$ in acetic anhydride transformed them into benzopyranodicoumarins $\mathbf{4 6}$ and $\mathbf{4 9}$ (Scheme 6).

Scheme 6. Synthesis of benzopyranodicoumarins 46 and 49.

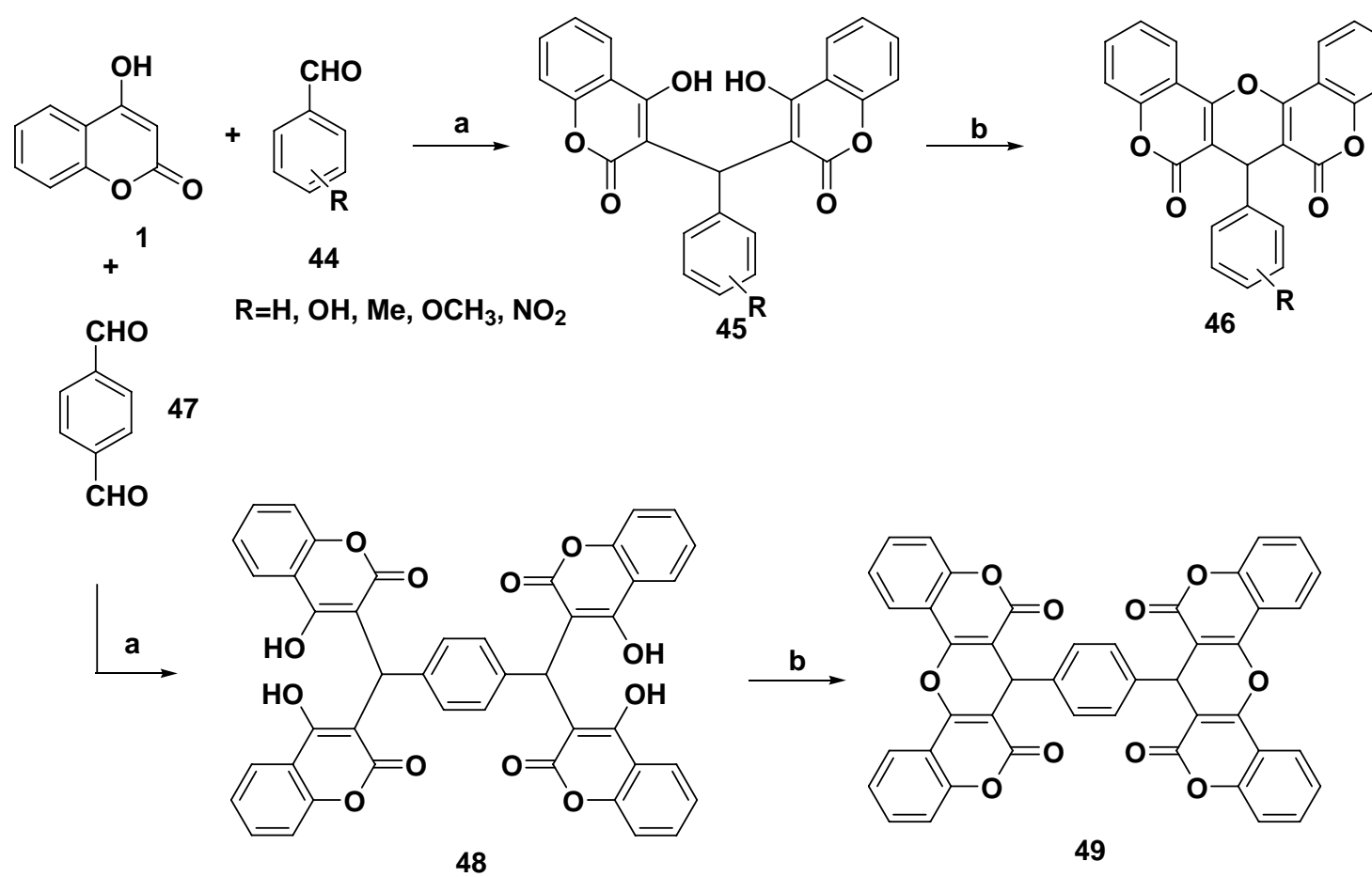

Reagents and conditions: (a) EtOH, AcOH, reflux; (b) $\left(\mathrm{CH}_{3} \mathrm{CO}\right)_{2} \mathrm{CO},-2 \mathrm{H}_{2} \mathrm{O}$.

On the other hand, the Raghunathan group [24] successfully established a pyrano[3-2c]coumarin framework using microwave accelerated intramolecular domino Knoevenagel-hetero Diels-Alder reactions. 4-Hydroxycoumarin (1) was treated with 2-(3-methyl-2-butenyloxy)benzaldehyde under microwave irradiation in ethanol for $15 \mathrm{~s}$ to give a 97:3 ratio of pyrano[3-2c]coumarin 51 and pyrano[3-2c]chromene derivative 52 in good yield (Scheme 7). This methodology is very useful, providing an easy access to the pyrano[3-2c]coumarin skeleton found in many natural products.

Scheme 7. Synthesis of pyrano[3-2c] coumarins.<smiles>O=c1cc(O)c2ccccc2o1</smiles>

1<smiles>CC(C)=CCOc1ccccc1C=O</smiles>

50<smiles>CC1(C)Oc2c(c(=O)oc3ccccc23)C2COc3ccccc3C21</smiles>

51<smiles>CC1(C)Oc2oc3ccccc3c(=O)c2[C@H]2COc3ccccc3[C@H]21</smiles>

52

Reagents and conditions: (a) EtOH reflux 4 h, or microwave irradiation, $15 \mathrm{~s}$. 
The Trkovnik group [25] synthesized substituted 4-hydroxycoumarins $\mathbf{5 4}$ and $\mathbf{5 6}$ from compounds 53 and 55 according to a modified Pauly and Lockemann method [26], respectively. They also prepared dicoumairn type moiety 59 in good yield (Scheme 8).

Scheme 8. Synthesis of substituted 4-hydroxycoumarins 54 and 56 and dicoumairn 59.<smiles>COC(=O)c1ccc(Br)cc1C(C)=O</smiles>

53<smiles>COC(=O)c1cc2ccccc2cc1C(=O)OC</smiles>

55



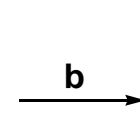<smiles>O=c1cc(O)c2cc3ccccc3cc2o1</smiles>

56<smiles>O=c1cc(O)c2cc(Br)ccc2o1</smiles>

57<smiles>[R]Cc1c(O)c2cc(Br)ccc2oc1=O</smiles>

59

$$
\mathbf{R}=\text { alkyl group }
$$

Reagents and conditions: (a) sodium, paraffin, $220-240{ }^{\circ} \mathrm{C}$; (b) sodium, paraffin, $220-230{ }^{\circ} \mathrm{C}$; (c) $\mathrm{POCl}_{3}$, reflux.

The Swenson group [27] recently published a unique procedure for preparation of 3-(p-azido, amino, and nitrobenzyl)-4-hydroxycoumarins 62-64 by the reaction of freshly prepared benzyl malonic acid 60 and phenol (61) in the presence of phosphorus trichloride and zinc chloride (Scheme 9). They also prepared various radiolabeled 3-substituted 4-hydroxycoumarin derivatives using commercially available $\left[\mathrm{U}_{-}{ }^{14} \mathrm{C}\right]$ phenol or $\left[\mathrm{U}_{-}{ }^{3} \mathrm{H}\right]$ in order to elucidate the binding photoaffinity. Compounds 62-64 serve as effective competitive inhibitors of the dicoumarol sensitive NADPH quinone reductase from rat liver [28,29].

Scheme 9. Synthesis of 3-(p-azido, amino, and nitrobenzyl)-4-hydroxycoumarins 62-64.<smiles>O=C(O)C(Cc1ccc([N+](=O)[O-])cc1)C(=O)O</smiles>

60<smiles>Oc1ccccc1</smiles>

61

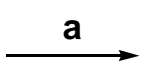<smiles>[R]c1ccc(Cc2c(O)c3ccccc3oc2=O)cc1</smiles>

Reagents and conditions: (a) $\mathrm{POCl}_{3}, \mathrm{ZnCl}_{2}, 75{ }^{\circ} \mathrm{C}$; (b) $\mathrm{FeSO}_{4}, \mathrm{H}_{2} \mathrm{O}, \mathrm{NH}_{4} \mathrm{OH}, 80{ }^{\circ} \mathrm{C}$; (c) $\mathrm{NaNO}_{2}$, $\mathrm{HCl}$, and then $\mathrm{NaN}_{3}, 4{ }^{\circ} \mathrm{C}$. 
Recently, stereoselective synthesis has been an important topic in the synthesis of biologically active substances. Efficient asymmetric syntheses of 4-hydroxycoumarin derivatives were demonstrated by two groups. The Ferreira group [30] firstly reported a highly stereo- and enantioselective synthesis of diphenacoum (29) and brodifacoum (30). The key step involves a stereospecific 1,4-Michael addition using a chiral auxiliary and intramolecular ring cyclization. The esters 21, 22 were transformed into acid chlorides through hydrolysis and chlorination with $\mathrm{KOH}$ and $\mathrm{SOCl}_{2}$, and subsequently reacted with the lithium anion of the chiral auxiliary to afford the chiral imides 65-68 in $72 \%, 74 \%, 73 \%$, and 70\% yield, respectively, for three steps. Asymmetric 1,4-Michael addition of imides 65-68 was accomplished with $\mathrm{Bn}-\mathrm{Cu}$-TMEDA complex in the presence of $\mathrm{Bu}_{2} \mathrm{BOTf}$ to give diastereoisomeric ketones 69-72, which were effectively cyclized using trifluoromethanesulfonic acid to generate chiral tetralones 73-76 with $99 \%$ optical purity in $85 \%, 84 \%, 79 \%$, and $80 \%$ yield, respectively. Reduction of tetralones 73-76 with sodium borohydride afforded the corresponding cis benzyl alcohols, which were condensed with 4-hydroxcoumarin (1) to give cis/trans diphenacoum and brodifacoum, respectively (Scheme 10). The stereoisomeric mixtures were readily separated by flash column chromatography. The configuration was established using spectroscopic analysis.

Scheme 10. Stereo- and enantioselective synthesis of diphenacoum (29) and brodifacoum (30).
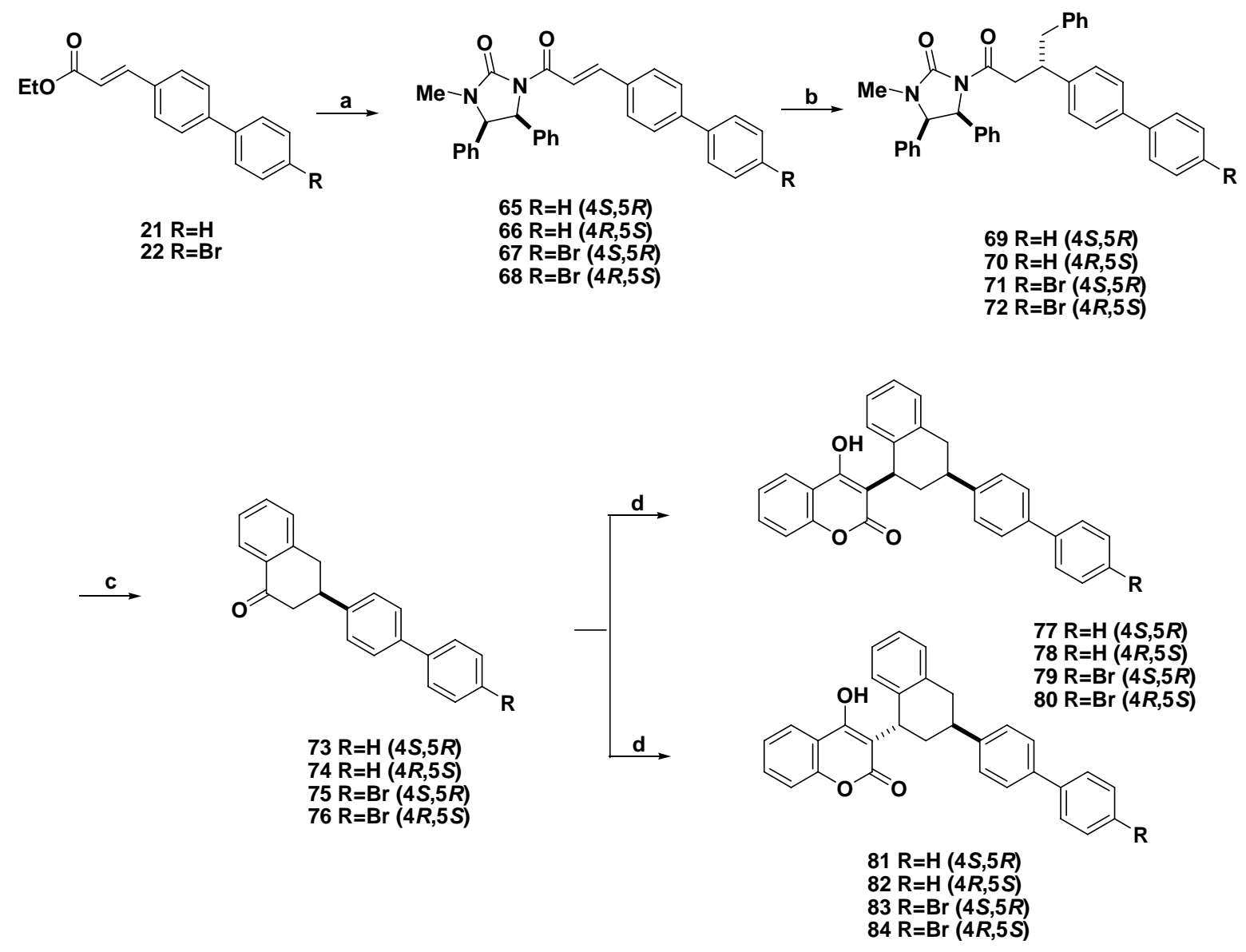

Reagents and conditions: (a) $\mathrm{KOH}, \mathrm{EtOH}, 40{ }^{\circ} \mathrm{C}$; $\mathrm{SOCl}_{2}$, rt, (+)- or (-)-1,5-dimethyl-4-phenyl-2imidazolidinone, $n$-BuLi, $\mathrm{Ph}_{3} \mathrm{CH}$, THF, $0{ }^{\circ} \mathrm{C}$; (b) BnCu-TMEDA- $n$-Bu $\mathrm{Bu}_{2} \mathrm{BOTf}$, THF, $-78{ }^{\circ} \mathrm{C}$ to $30{ }^{\circ} \mathrm{C}$; (c) $\mathrm{CF}_{3} \mathrm{SO}_{3} \mathrm{H}$, benzene, reflux; (d) $\mathrm{NaBH}_{4}$, EtOH/THF (1:1, v/v), then 4-hydroxycoumarin, $\mathrm{HCl}(\mathrm{g}), 160^{\circ} \mathrm{C}$. 
The Jorgensen group [31] reported a highly economical organocatalytic asymmetric 1,4-Michael addition of 4-hydroxycoumarin and $\alpha, \beta$-unsaturated ketones to generate the widely used anticoagulants warfarin (Coumadin) and some related important compounds (Scheme 11). They attempted enantioselective 1,4-Michael addition by using well known benzylideneacetophenone (85) and 4-hydroxycoumarin (1) in the presence of optically active imidazolidine catalysts $\mathbf{8 6 - 8 8}$ to afford enantiopure warfarin moieties with 47 to $82 \%$ ee values in 22 to $96 \%$ yields. This asymmetric one-step method could be useful for the formation of a number of biologically active compounds.

Scheme 11. Organocatalytic asymmetric 1,4-Michael addition of 4-hydroxycoumarin and $\alpha, \beta$-unsaturated ketones.<smiles>O=c1cc(O)c2ccccc2o1</smiles>

1<smiles>CN1CC(Cc2ccccc2)NC1C(=O)O</smiles>

86<smiles>CC(=O)/C=C/c1ccccc1</smiles>

85<smiles>CN1CC(c2ccccc2)NC1C(=O)O</smiles>

87<smiles>CC(=O)CC(c1ccccc1)c1c(O)c2ccccc2oc1=O</smiles>

3<smiles>CN1[C@H](C(=O)O)NC(c2ccccc2)[C@H]1c1ccccc1</smiles>

88

Reagents and conditions: (a) $10 \mathrm{~mol} \%$ catalysts $\mathbf{8 6 - 8 8}$, dichloromethane, $\mathrm{rt}$.

The Tagliapietra group [32] developed an asymmetric two-step synthesis of non-racemic coumarin anticoagulants such like warfarin, coumachlor, and acenocoumarol through one-pot-three-component tandem Knoevenagel-hetero Diels-Alder cycloaddition reactions between in situ generated 3-arylidene-2,4-chromanediones 89 and isopropenyl ether 90 derived from (-)-menthol in 61\% yield with $95 \%$ ee for $(S)$-warfarin, $56 \%$ yield with $93 \%$ ee for $(S)$-coumachlor, and $59 \%$ yield with $95 \%$ ee for $(S)$-acenocoumarol (Scheme 12). Knoevenagel adducts 91 were treated with $3 \mathrm{~N}-\mathrm{HCl}$ in the presence of $\mathrm{SiO}_{2}$ or TFA: $\mathrm{H}_{2} \mathrm{O}(19: 1, \mathrm{v} / \mathrm{v})$ as a reaction promotor to get the final asymmetric products 92 in nearly quantitative yields.

Scheme 12. Asymmetric two-step synthesis of non-racemic coumarin anticoagulants.<smiles>[X]c1ccc(/C=C2\C(=O)Oc3ccccc3C2=O)cc1</smiles>

$\mathrm{X}=\mathrm{H}, \mathrm{Cl}, \mathrm{NO}_{2}$



90<smiles>[X]c1ccc([C@H]2CC([R2])([R])Oc3c2c(=O)oc2ccccc32)cc1</smiles>

91<smiles>[X]c1ccc(C(CC(C)=O)c2c(O)c3ccccc3oc2=O)cc1</smiles>

92

89

Reagents and conditions: (a) cat-ethylenediammonium diacetate (Tietze base), 5 A molecular sieves, dioxane, $90^{\circ} \mathrm{C}$, screw cap pressure tube; (b) $3 \mathrm{~N}-\mathrm{HCl}, \mathrm{SiO}_{2}$, or TFA: $\mathrm{H}_{2} \mathrm{O}(19: 1, \mathrm{v} / \mathrm{v})$. 


\section{Biological Activity}

A large number of 4-hydroxycoumarins and their derivatives have been synthesized and evaluated for their ability to play a positive role in the prevention of human and animal diseases. Various pharmacological activities for the representative compounds have been described in the literature (Table 1). Most 4-hydroxycoumarin derivatives showed representative anticoagulant effects, while compounds 3, 5, 30, 40, 46, and 64 exhibit a wide variety of activities including antiarthritis, antiinflammatory, anticancer, antithrombosis, teratogenic, antibacterial, and photoaffinity effects.

Table 1. Biological activities for 4-hydroxycoumarin derivatives.

\begin{tabular}{|c|c|c|}
\hline 4-Hydroxycoumarin & Biological activity & References \\
\hline 3 & $\begin{array}{c}\text { arthritis, anti-inflammatory } \\
\text { anti-cancer, anticoagulant }\end{array}$ & {$[33-34]$} \\
& antithrombosis & {$[35-36]$} \\
$\mathbf{4}$ & anticoagulant & {$[37]$} \\
$\mathbf{5}$ & anticoagulant, teratogenic & {$[38]$} \\
$\mathbf{6}$ & anticoagulant & {$[39-40]$} \\
$\mathbf{2 9}$ & anticoagulant & {$[41]$} \\
$\mathbf{3 0}$ & teratogenic & {$[42]$} \\
$\mathbf{4 0}$ & inhibitors & {$[43]$} \\
$\mathbf{4 1}$ & anticoagulant & {$[21]$} \\
$\mathbf{4 3}$ & anticoagulant & {$[44]$} \\
$\mathbf{4 6}$ & anti-bacterial & {$[45]$} \\
$\mathbf{5 4}$ & anticoagulant & {$[23]$} \\
$\mathbf{5 6}$ & anticoagulant & {$[25]$} \\
$\mathbf{6 4}$ & photoaffinity & {$[25]$} \\
$\mathbf{9 2}$ & anticoagulant & {$[46]$} \\
\hline
\end{tabular}

Anticoagulant is the most prominent among many intriguing pharmacological effects observed for many 4-hydroxycoumarin derivatives. In particular warfarin, as first generation anticoagulant, and compounds like brodifacoum, bromadiolone, chlorophacinone, difenacoum, coumatetralyl, flocoumafen, and difethialone are effective anticoagulant rodenticides. The second generation anticoagulant rodenticides, difenacoum (29) and brodifacoum (30) showed a plasma elimination halflife of 91.7 days, while liver elimination half-lives varied from 15.8 days for coumatetralyl (4) to 307.4 days for brodifacoum. In general, the elimination half-lives in plasma for first-generation rodenticides were shorter than those for second-generation rodenticides. These results revealed that the so-called superwarfarins such as difenacoum (29), brodifacoum (30), flocoumafen (5), and difethialone (6) showed higher anticoagulant effects than warfarin [48]. The biological activities of compounds 40 and 41 indicate potent vitamin K 2,3-epoxide reductase (VKOR) inhibition effects with $\mathrm{IC}_{50}$ values of $0.4 \mu \mathrm{M}$, comparable with warfarin. Compound $\mathbf{4 0}$ was shown to be 2.5 -fold more potent than warfarin, while compound $\mathbf{4 1}$ exhibited 10 times less activity than warfarin. These biological results imply that the hydrogen bonding has a major effect on enzyme site binding [21]. 4-Hydroxycoumarin derivatives 43 showed favorable anticoagulant effect compared with warfarin; especially a chlorine at the para- 
position in the aromatic ring resulted in potent anticoagulant activities compared to nitro or other halogen substituents at the para-position [22,49]. The dicoumarol related compounds $48-49$ were evaluated for antimicrobial, antioxidant activities using MIC tests and radical scavenging activities. Also, compounds 48 and $\mathbf{4 9}$ showed favorable antimicrobial activity compared to warfarin and similar effects to each other for the antioxidant activity. In addition, the coumarol moiety showed more potent activity than a benzopyranocoumarol moiety due to the stable configuration and favorable binding activity through hydrogen bonding in the enzyme binding site [22]. 6-Bromo-4-hydroxycoumarin (54) and 4-hydroxy-6,7-benzocoumarin (56) exhibited significant anticoagulant effect with a rapid short duration. Especially 3,3'-alkylidene bis-6-bromo-4-hydroxycoumarin derivatives showed a potent anticoagulant activity in vitro [25].

A 4-hydroxycoumarin containing an azidobenzyl group at the 3-position - 3-(p-azidobenzyl)-4hydroxycoumarin (64) - showed an inhibition constant of $6.6 \times 10^{-8} \mathrm{M}$, a value comparable to that observed for dicoumarol $\left(1.7 \times 10^{-9} \mathrm{M}\right)$, but significantly lower than that for warfarin $\left(3.5 \times 10^{-5} \mathrm{M}\right)$. This result implies that compound $\mathbf{6 4}$ can be an effective photoaffinity probe in the identification of other proteins associated with the vitamin K-dependent carboxylation system that are similarly inhibited by 4-hydroxycoumarin derivatives [46].

\section{Conclusions}

The chemical syntheses and structural modifications of 4-hydroxycoumarin and its derivatives are of interest due to their biological activities and characteristic conjugated molecular architecture. This review summarized the recent synthetic approaches to 4-hydroxycoumarin derivatives and the current state of research into their biological activities.

\section{Acknowledgments}

This work was supported by a Chungbuk National University Grant in 2008.

\section{References and Notes}

1. Adami, E.; Marazzi-Uberti, E.; Turba, C. Analgesic action of 4-hydroxycoumarin. Arch. Ital. Sci. Farmacol. 1959, 9, 61-69.

2. Chiarino, D.; Grancini, G.C.; Frigeni, V.; Carenzi, A. Preparation and formulation of 4-(3coumarinyl)thiazole derivatives with antiallergic, antianaphylactic and antiarthritic activity. Eur. Pat. Appl. EP 284017, 1988.

3. Luchini, A.C.; Rodrigues-Orsi, P.; Cestari, S.H.; Seito, L.N.; Witaicenis, A.; Pellizzon, C.H.; Stasi, L.C.D. Intestinal anti-inflammatory activity of coumarin and 4-hydroxycoumarin in the trinitrobenzenesulphonic acid model of rat colitis. Biol. Pharm. Bull. 2008, 31, 1343-1350.

4. Stern, P.; Dezelic, M.; Kosak, R. Analgetic and antipyretic action of vitamin K and dicoumarol with special consideration of 4-hydroxycoumarin. Naunyn Schmiedebergs Arch. Exp. Pathol. Pharmakol. 1957, 232, 356-359. 
5. Chohan, Z.H.; Shaikh, A.U.; Rauf, A.; Supuran, C.T. Antibacterial, antifungal and cytotoxic properties of novel $\mathrm{N}$-substituted sulfonamides from 4-hydroxycoumarin. J. Enz. Inhib. Med. Chem. 2006, 21, 741-748.

6. Kirkiacharian, B.S.; Clercq, E.; Kurkjian, R.; Pannecouque, C. New synthesis and anti-HIV and antiviral properties of 3-arylsulfonyl derivatives of 4-hydroxycoumarin and 4-hydroxyquinolone. J. Pharm. Chem. 2008, 42, 265-270.

7. Velasco-Velázquez, M.A.; Agramonte-Hevia, J.; Barrera, D.; Jiménez-Orozco, A.; GarcíaMondragón, M.J.; Mendoza-Patiño, N.; Landa, A.; Mandoki, J. 4-Hydroxycoumarin disorganizes the actin cytoskeleton in B16-F10 melanoma cells but not in B82 fibroblasts, decreasing their adhesion to extracellular matrix proteins and motility. Cancer Lett. 2003, 198, 179-186.

8. Shapiro, S.; Sherwin, B. Thromboembolization. II. The use of dicumarol (3,3'-methylenebis (4hydroxycoumarin ) in embolization. Report of five cases. N. Y. State J. Med. 1943, 43, 45-52.

9. Butsch, W.L.; Stewart, J.D. Administration of dicoumarin compound for prophylaxis of postoperative thrombosis and embolism. Arch. Surg. 1942, 45, 551-553.

10. Hintz K.K; Ren J. Tetramethylpyrazine elicits disparate responses in cardiac contraction and intracellular $\mathrm{Ca}(2+)$ transients in isolated adult rat ventricular myocytes. Vascul. Pharmacol. 2003, 40, 213-217.

11. Manolov, I.; Maichle-Moessmer, C.; Danchev, N. Synthesis, structure, toxicological and pharmacological investigations of 4-hydroxycoumarin derivatives. Eur. J. Med. Chem. 2006, 41, 882-890.

12. Samama, M.M. A century of progress. From biology to antithrombotic agents. J. Mal. Vasc. 2001, 26, 165-168.

13. Bulut, M.; Erk, C. Improved synthesis of some hydroxycoumarins. Dyes Pigments 1996, 30, 99-104.

14. Kang, H.; Kwon, K.S.; Kang, D.; Lee, J.C. Enhanced, perpendicular liquid-crystal alignment on rubbed films of a coumarin-containing polystyrene. Macromol. Chem. Phys. 2007, 208, 1853-1861.

15. Au, N.; Rettie, A.E. Pharmacogenomics of 4-hydroxycoumarin anticoagulants. Drug Metab. Rev. 2008, 40, 355-375.

16. Hamdi, N.; Saoud, M.; Romerosa, A. 4-Hydroxy Coumarine: A versatile reagent for the synthesis of heterocyclic and vanillin ether coumarins with biological activities. Top. Heterocycl. Chem. 2007, 11, 283-301.

17. Hamdi, N.; Saoud, M.; Romerosa, A.; Hassen R.B. Synthesis, spectroscopic and antibacterial investigations of new hydroxy ethers and heterocyclic coumarin derivatives. J. Heterocycl. Chem. 2008, 45, 1835-1841.

18. Park, O.S.; Jang, B.S. Synthesis of 4-hydroxycoumarin derivatives-1: An efficient synthesis of flocoumafen. Arch. Pharm. Res. 1995, 18, 277-281.

19. Jung, J.C.; Lee, J.H.; Oh, S.; Lee, J.G.; Park, O.S. Synthesis and antitumor activity of 4-hydroxycoumarin derivatives. Bioorg. Med. Chem. Lett. 2004, 14, 5527-5531.

20. Van Heerden, P.S.; Bezuidenhoudt, B.C.B.; Ferreira, D. Improved synthesis of the rodenticides diphenacoum and brodifacoum. J. Chem. Soc. Perkin Trans. 1 1997, 8, 1141-1146.

21. Chen, D.U.; Kuo, P.Y.; Yang, D.Y. Design and synthesis of novel diphenacoum-derived, 
conformation-restricted vitamin K 2,3-epoxide reductase inhibitors. Bioorg. Med. Chem. Lett. 2005, 15, 2665-2668.

22. Manolov, I.; Danchev, N.D. Synthesis, toxicological, and pharmacological assessment of some oximes and aldehyde condensation products of 4-hydroxycoumarin. Arch. Pharm. Pharm. Med. Chem. 1999, 332, 243-248.

23. Hamdi, N.; Puerta, M.C.; Valerga, P. Synthesis, structure, antimicrobial and antioxidant investigations of dicoumarol and related compounds. Euro. J. Med. Chem. 2008, 43, 2541-2548.

24. Shanmugasundaram, M.; Manikandan, S.; Raghunathan, R. High chemoselectivity in microwave accelerated intramolecular domino Knoevenagel hetero Diels-Alder reactions- an efficient synthesis of pyrano[3-2c]coumarin frameworks. Tetrahedron 2002, 58, 997-1003.

25. Dezelic, M.; Trkovnik, M. Syntheses of some 4-hydroxycoumarins and their condensation products with aldehydes and carboxylic acids. Anticoagulant activity of some 4-hydroxycoumarin derivatives. J. Med. Chem. 1964, 7, 284-288.

26. Pauly, H.; Lockemann, K. Methods of formation of monophenol ketones and a new synthesis of benzotetronic acid. Ber. Dtsch. Chem. Ges. 1915, 48, 28-32.

27. Myszka, D.G.; Swenson, R.P. Synthesis of the photoaffinity probe 3-(p-azidobenzyl)-4hydroxycoumarin and identification of the dicoumarol binding site in rat liver NAD(P)H: Quinone reductase (EC 1.6.99.2). J. Biol. Chem. 1991, 266, 4789-4797.

28. Almeda, S.; Bing, D.H.; Laura, R.; Friedman, P.A. Photoaffinity inhibition of rat liver NAD(P)H dehydrogenase by 3-( $\alpha$-acetonyl-p-azidobenzyl)-4-hydroxycoumarin. Biochemistry 1981, 20, 3731-3737.

29. Obach, R.S.; Spink, D.C.; Chen, N.; Kaminsky, L.S. Azidowarfarin photoaffinity probes of purified rat liver cytochrome P4501A1. Arch. Biochem. Bioph. 1992, 294, 215-222.

30. Van Heerden, P.S.; Bezuidenhoudt, B.C.B.; Ferreira, D. Efficient asymmetric synthesis of the four diastereomers of diphenacoum and brodifacoum. Tetrahedron 1997, 53, 6045-6056.

31. Halland, N.; Hansen, T.; Jorgensen, K.A. Organocatalytic asymmetric Michael reaction of cyclic 1, 3-dicarbonyl compounds and $\alpha, \beta$-unsaturated ketones-A highly atom-economic catalytic onestep formation of optically active warfarin anticoagulant. Angew. Chem. Int. Ed. 2003, 42, 4955-4957.

32. Cravotto, G.; Nano, G.M.; Palmisano, G.; Tagliapietra, S. An asymmetric approach to coumarin anticoagulants via hetero-Diels-Alder cycloaddition. Tetrahedron Asymmetry 2001, 12, 707-709.

33. Thumboo, J.; O'Duffy, J.D. A prospective study of the safety of joint and soft tissue aspirations and injections in patients taking warfarin sodium. Arthritis Rheum. 1998, 41, 736-739.

34. Eichbaum, F.W.; Slemer, O.; Zyngier, S.B. Antiinflammatory effect of warfarin and vitamin K1. Naunyn Schmiedeberg Arch. Pharmacol. 1979, 307, 185-190.

35. Colucci, M.; Delaini, F.; De Bellis Vitti, G.; Locati, D.; Poggi, A.; Semeraro, N.; Donati, M.B. Cancer cell procoagulant activity, Warfarin and experimental metastases. Dev. Oncol. 1980, 4, 90-94.

36. Sutcliffe, F.A.; MacNicoll, A.D.; Gibson, G.G. Aspects of anticoagulant action: A review of the pharmacology, metabolism and toxicology of warfarin and congeners. Rev. Drug Metab. Drug Interact. 1987, 5, 225-272. 
37. Wessler, S.; Gitel, S.N.; Bank, H.; Martinowitz, U.; Stephenson, R.C. An assay of the antithrombotic action of warfarin: Its correlation with the inhibition of stasis thrombosis in rabbits. Thromb. Haemost. 1979, 40, 486-498.

38. Marchini, S.; Turillazzi, P.G. Effect of an anticoagulant rodenticide on the female albino rat with offspring. Parassitologia 1978, 20, 59-70.

39. Saxena, Y.; Bhasin, H. Novel second generation anticoagulants against field rodents. Natl. Acad. Sci. Lett. 1991, 14, 483-485.

40. Khalifa, B.A.A.; Salem, F.M.S.; Menha, M.A. Embryotoxic and teratogenic effects of flocoumafen in chick embryos and white rats. J. Appl. Anim. Res. 1992, 2, 81-85.

41. Chaudhary, V.; Tripathi, R.S. Evaluation of single dose efficacy of difethialone - a secondgeneration anticoagulant for the control of rodents inhabiting arid ecosystem. Indian J. Agr. Sci. 2006, 76, 736-739.

42. Shore, R.F.; Birks, J.D.S.; Afsar, A.; Wienburg, C.L.; Kitchener, A.C. Spatial and temporal analysis of second-generation anticoagulant rodenticide residues in polecats (Mustela putorius) from throughout their range in Britain, 1992-1999. Environ. Pollut. 2003, 122, 183-193.

43. Zurawski, J.M.; Kelly, E.A. Pregnancy outcome after maternal poisoning with brodifacoum, a long-acting warfarin-like rodenticide. Obstet. Gynecol. 1997, 90, 672-674.

44. Hadler, M.R.; Shadbolt, R.S. Novel 4-hydroxycoumarin anticoagulants active against resistant rats. Nature 1975, 253, 275-277.

45. Beier, A.P.; Popov, V.A.; Efremenko, V.I. The effect of anticoagulants on the transmission of plague causative agent. Med. Parazitol (Mosk) 1999, 2, 40-43.

46. Myszka, D.G.; Swenson, R.P. Synthesis of 3-(4-azido-5-iodosalicylamido)-4- hydroxycoumarin: Photoaffinity labeling of rat liver dicoumarol-sensitive NAD $(\mathrm{P}) \mathrm{H}$ : Quinone reductase. Biochem. Bioph. Res. Commun. 1990, 172, 415-422.

47. Rehman, A.B.; Ahmad, S.I. Studies on warfarin, coumatetralyl and difenacoum as anticoagulant agents. J. Pharm. 1982, 1, 1-13.

48. Vandenbroucke, V.; Bousquet-Melou, A.; De Backer, P.; Croubels, S. Pharmacokinetics of eight anticoagulant rodenticides in mice affer single oral administration. J. Vet. Pharmacol. Ther. 2008, 31, 437-445.

49. Manolov, I.; Danchev, N.D. Synthesis, toxicological and pharmacological assessment of some 4hydroxycoumarin derivatives. Eur. J. Med. Chem. 1995, 30, 531-535.

Sample Availability: Samples of the compounds 1, 2, 5, 15, 16 and 17 are available from the authors.

(C) 2009 by the authors; licensee Molecular Diversity Preservation International, Basel, Switzerland. This article is an open-access article distributed under the terms and conditions of the Creative Commons Attribution license (http://creativecommons.org/licenses/by/3.0/). 